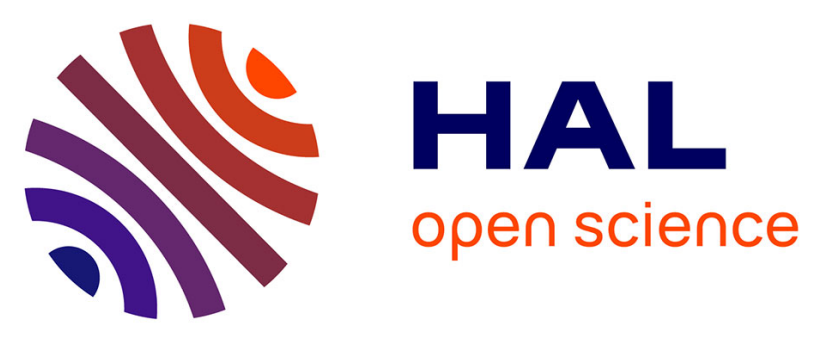

\title{
Tracing calcite precipitation with specific conductance in a hard water alpine lake (Lake Bourget)
}

A. Groleau, G Sarazin, Brigitte Vinçon-Leite, Bruno Tassin, C. Quiblier-Lloberas

\section{- To cite this version:}

A. Groleau, G Sarazin, Brigitte Vinçon-Leite, Bruno Tassin, C. Quiblier-Lloberas. Tracing calcite precipitation with specific conductance in a hard water alpine lake (Lake Bourget). Water Research, 2000, 34 (17), pp.4151-4160. 10.1016/S0043-1354(00)00191-3 . hal-00711823

HAL Id: hal-00711823

https://hal-enpc.archives-ouvertes.fr/hal-00711823

Submitted on 29 Mar 2015

HAL is a multi-disciplinary open access archive for the deposit and dissemination of scientific research documents, whether they are published or not. The documents may come from teaching and research institutions in France or abroad, or from public or private research centers.
L'archive ouverte pluridisciplinaire HAL, est destinée au dépôt et à la diffusion de documents scientifiques de niveau recherche, publiés ou non, émanant des établissements d'enseignement et de recherche français ou étrangers, des laboratoires publics ou privés. 


\title{
PERGAMON
}

www.elsevier.com/locate/watres

\section{TRACING CALCITE PRECIPITATION WITH SPECIFIC CONDUCTANCE IN A HARD WATER ALPINE LAKE (LAKE BOURGET)}

\author{
A. GROLEAU ${ }^{1 *}$, G. SARAZIN ${ }^{2}$, B. VINÇON-LEITE ${ }^{1}$, B. $_{\text {TASSIN }}^{1}$ and \\ C. QUIBLIER-LLOBÉRAS ${ }^{2}$ \\ ${ }^{1}$ CEREVE-ENPC, 6-8 ave, Blaise Pascal, Champs sur Marne, 77455 Marne la Vallée Cedex 2 \\ France and ${ }^{2}$ Laboratoire de Géochimie des Eaux, Université Denis Diderot-Paris 7, Case postale \\ 7052, 2 place Jussieu, 75251, Paris, Cedex 05, France
}

(First received 13 July 1999)

\begin{abstract}
The authors discuss the reliability of a new method used to depict precisely the authigenic calcite precipitation process in the water column of a mesotrophic alpine lake (Lake Bourget, Savoie, France). Complete chemical analysis of dissolved major elements shows that, in the epilimnion, calcium concentration and alkalinity are the only chemical species presenting large variations. The behaviour of these two parameters is only related to calcite precipitation. The method is based on in situ specific conductance measurements $\left(C_{25}\right)$. Experimental values were compared with theoretical calculations. The results demonstrate clearly that dissolved calcium concentration can be directly related to measured specific conductance. Hence, a mathematical relationship was developed to compute calcium concentration profiles in the water column with a centimetre spatial resolution through the whole water column. Finally, authigenic calcite production can be observed and quantified on a time scale covering two years of experimental data. Calcite production is estimated to $4.8 \mathrm{~mol} \mathrm{~m}^{-2} \mathrm{yr}^{-1}$. Extrapolation to the whole lake surface leads to $16,000 \pm 2000$ tons $\mathrm{yr}^{-1}$ as $\mathrm{CaCO}_{3}$. Specific conductance is an easy-tomeasure in situ parameter which could be used to trace authigenic calcite production in other hard water alpine lakes. (C) 2000 Elsevier Science Ltd. All rights reserved
\end{abstract}

Key words - alpine lake, calcite precipitation, specific conductance, in situ measurements, conductivity

\section{INTRODUCTION}

Authigenic calcite precipitation is a well known geochemical process in hard water lakes. Precipitation is initiated and sustained by both temperature elevation of the epilimnion and by the development of phytoplankton. Algal cells are supposed to offer nucleation sites for starting the crystal growth (Stabel, 1986; Kuchler-Krischun and Kleiner, 1990; Hartley et al., 1996). Calcite precipitation can also be closely linked to the phosphorus cycle in lakes because coprecipitation of phosphate with calcite is reported as an important phosphorus sink in the Pbudget in lakes (Otzuki and Wetzel, 1972; Murphy et al., 1983; Vinçon-Leite et al., 1995; Hartley et al., 1997).

In order to describe the characteristics of the calcite precipitation process in lakes, three classical methods can be used. The first one consists of a survey of specific dissolved chemical parameters, such as calcium concentration or alkalinity by

\footnotetext{
*Author to whom all correspondence should be addressed. Tel.: + 33-1-64-15-3642; fax: +33-1-64-15-3764; e-mail: groleau@cereve.enpc.fr
}

sampling the water column (Salmaso and Decet, 1998; Kuchler-Krischun and Kleiner, 1990; Weilenmann, 1986). This method requires a large number of chemical analyses which in turn limits the time and spatial scale of sampling. The second method consists of measuring the sedimentation fluxes with sediment traps. Analysis of the collected solids yields an estimate of the calcite flux (Stabel, 1986; Stabel and Chondrogianni, 1988; Hodell et al., 1998). These two methods are effective, however, they require heavy sampling and analysis programmes. The third method consists of a calcium mass balance on the lake, by evaluating the tributary inputs and the lake outputs (Decet and Salmaso, 1997). The accuracy of the balance method depends on the hydrological regime of the affluents, especially during flood events, when uncertainties in the flux calculations are likely to increase drastically.

The objective of this paper is to present a different method for quantifying the calcite precipitation in the water column of lakes based on in situ measurements of specific conductance. This method leads to a "software sensor", which is a recent concept related to the computation and estimation of 
some quantity of interest, using both measurements and a theoretical model (Masson et al., 1998).

To proceed with this objective, the main biogeochemical processes occurring in Lake Bourget and their order of magnitude are presented. Then, on this basis, the theoretical model of the software sensor and its validation is explained. Finally, this new method for tracing calcite precipitation is applied on Lake Bourget in order to assess the magnitude of the process, and to demonstrate the advantages from this new approach.

\section{MATERIALS AND METHODS}

\section{Study site}

Lake Bourget is a medium sized lake (surface area $42 \mathrm{~km}^{2}$, maximal depth: $145 \mathrm{~m}$, water residence time: seven years) located in the French Alps (Fig. 1). The watershed $\left(560 \mathrm{~km}^{2}\right)$ encloses two cities (Chambéry and Aix-les-Bains) which through inputs of industrial and domestic sewage, have led to eutrophication of the water body during the 1970s. Since 1980 an important restoration plan has drastically reduced phosphorus input to the lake. This study is focused on both the spring-summer 1997 and 1998 periods for the following reasons:

- These periods are short with regard to the water residence time (seven years).

- No high flow was recorded during these periods.

- The sampling point (point B) located at the maximum depth is not influenced by the main tributary (Leysse river).

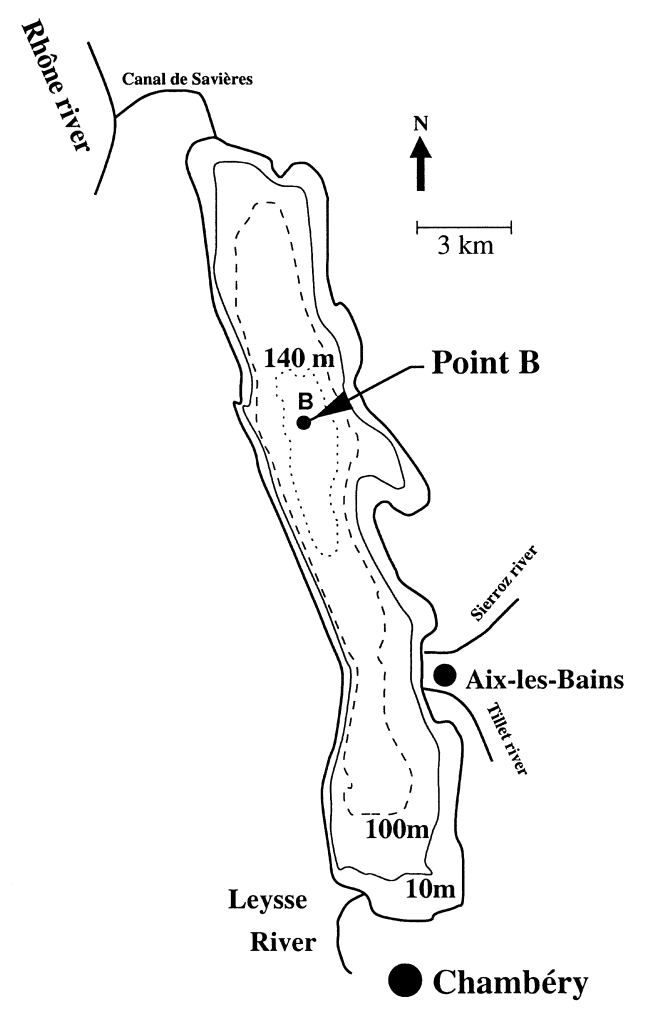

Fig. 1. Map of the study site.
Therefore, there is no direct impact of the tributaries nor direct watershed runoff on the lake water composition. Previous studies show that point B is a representative station for the lake water composition (Vinçon-Leite et al., 1998). In addition, hydrodynamical studies have shown that the vertical displacement of the thermocline due to internal waves at point $B$ remains weak and that the measurements are not affected by this physical phenomenon (Bournet, 1996).

\section{Data collection}

In situ measurements and water sampling were processed monthly or biweekly during two years (April 1997 to February 1999) in the water column at point B (Fig. 1).

In situ measurements of temperature, $\mathrm{pH}$, conductivity and dissolved oxygen were performed using a multi-parameter Sea-Bird SBE 19 profiler. The probe data are recorded with a $0.15 \mathrm{~m}$ space step from surface to the bottom. The $\mathrm{pH}$ is measured with a pressure-balanced glasselectrode $/ \mathrm{Ag} / \mathrm{AgCl}$ reference $( \pm 0.05 \mathrm{pH}$ unit). The dissolved oxygen probe is a polarographic electrode YSI $5739( \pm 0.1 \mathrm{ppm})$, conductivity sensor returns values within $\pm 1 \mu \mathrm{S} \mathrm{cm}^{-1}$. The computation of specific conductance (conductivity corrected to $25^{\circ} \mathrm{C}=C_{25}$ ) is performed by a Seabird software using equation (1) (APHA, 1989):

$$
C_{25}=\frac{C * 10,000}{1+0.020 *(T-25)}
$$

where $C_{25}$ is the specific conductance in $\mu$ mhos $\mathrm{cm}^{-1}, C$ is the conductivity in $\mathrm{S} \mathrm{m}^{-1}$ and $T$ is the temperature in ${ }^{\circ} \mathrm{C}$.

The calibration of the $\mathrm{pH}$ probe was confirmed after each measuring survey against two NBS pH buffers $(\mathrm{pH}=4.01$ and $\mathrm{pH}=7.00$ at $298 \mathrm{~K}$ ). The calibration of conductivity cell was performed before first field deployment (April 1997). The water sampling was performed with a Niskin bottle at nine different depths (five samples in the epilimnion-metalimnion region and four samples in the hypolimnion). Immediately after sampling, the water used for major dissolved ion analysis was filtered on board with Minisart $^{(}$filters (porosity $0.45 \mu \mathrm{m}$ ). Alkalinity measurements were performed on filtered water within $6 \mathrm{~h}$ from sampling using the spectroscopic method (Sarazin et al., 1999; Podda and Michard, 1994) (accuracy $\pm 3 \%$ ). Total dissolved calcium, magnesium, potassium and sodium were analysed on acidified samples $\left(\mathrm{HNO}_{3}\right.$ Suprapur Merck $^{(}$) by a FAAS (accuracy $\pm 5 \%$ ). Major anions $\left(\mathrm{Cl}^{-}, \mathrm{NO}_{3}^{-}, \mathrm{SO}_{4}^{2-}\right)$ were analysed by ionic chromatography (Dionex 2000i; accuracy $\pm 3 \%$ ). Soluble reactive phosphorus (SRP), ammonium $\left(\mathrm{NH}_{4}^{+}\right)$and dissolved silica $\left(\mathrm{Si}_{t}\right)$ analysis were performed by the classical colorimetric methods (accuracy $\pm 5 \%$ ) (APHA, 1989). Individual concentrations of the carbonate system species $\left(\left[\mathrm{H}_{2} \mathrm{CO}_{3}\right]\right.$, $\left.\left[\mathrm{HCO}_{3}^{-}\right],\left[\mathrm{CO}_{3}^{2-}\right]\right)$ were calculated from measured data with a computer software derived from Mineql (Morel, 1983). Calculations take into account the following ion pair formations $\left(\mathrm{CaHCO}_{3}^{+}, \mathrm{CaCO}_{3}^{0}, \mathrm{CaSO}_{4}^{0}, \mathrm{MgHCO}_{3}^{+}, \mathrm{MgCO}_{3}^{0}\right.$, $\left.\mathrm{MgSO}_{4}^{0}, \mathrm{NaHCO}_{3}^{0}, \mathrm{NaCO}_{3}^{-}, \mathrm{NaSO}_{4}^{-}, \mathrm{KSO}_{4}^{-}\right)$and variations of temperature and pressure.

\section{CALCITE PRECIPITATION}

\section{Theoretical considerations}

The chemistry of carbonate and calcium in most alpine lakes involves essentially two reactions: calcite precipitation and photosynthesis-respiration (Sigg et al., 1994; Gaillard, 1995). These two main processes occur seasonally and affect the thermostratified zone (epilimnion).

Tables 1 and 2 display concentrations of the 
Table 1. Physical and chemical parameters measured in the epilimnion of the lake during April and June 1997

\begin{tabular}{|c|c|c|c|c|c|c|c|c|}
\hline Concentration $(\mu \mathrm{M})$ & $\mathrm{Ca}_{t}$ & $\mathrm{Mg}_{t}$ & $\mathrm{Na}_{t}$ & $\mathrm{~K}_{t}$ & Alk & $\mathrm{Cl}^{-}$ & $\mathrm{NO}_{3}^{-}$ & $\mathrm{SO}_{4}^{2-}$ \\
\hline April $2 \mathrm{~m}$ & 1390 & 245 & 221 & 39 & 2900 & 209 & 37 & 150 \\
\hline April $15 \mathrm{~m}$ & 1400 & 250 & 223 & 41 & 2870 & 211 & 38 & 161 \\
\hline June $2 \mathrm{~m}$ & 1080 & 246 & 211 & 43 & 2340 & 203 & 9 & 149 \\
\hline June $15 \mathrm{~m}$ & 1380 & 246 & 194 & 45 & 2850 & 211 & 37 & 153 \\
\hline Concentration & $\mathrm{SRP}(\mu \mathrm{M})$ & $\mathrm{NH}_{4}^{+}(\mu \mathrm{M})$ & $\mathrm{Si}_{t}(\mu \mathrm{M})$ & $\mathrm{O}_{2}(\mu \mathrm{M})$ & $\mathrm{pH}$ & Temperature $\left({ }^{\circ} \mathrm{C}\right)$ & $C_{25}\left(\mu \mathrm{S} \mathrm{cm}^{-1}\right)$ & \\
\hline April $2 \mathrm{~m}$ & 0.7 & 0.9 & 30.6 & 374 & 8.34 & 8.5 & 326 & \\
\hline April $15 \mathrm{~m}$ & 0.9 & 1.1 & 30.6 & 377 & 8.33 & 8.41 & 327 & \\
\hline June $2 \mathrm{~m}$ & 0 & 0.7 & 9.0 & 408 & 8.53 & 20.6 & 273 & \\
\hline June $15 \mathrm{~m}$ & 0 & 0.5 & 20.7 & 266 & 8.03 & 10.8 & 326 & \\
\hline
\end{tabular}

major dissolved ions and carbonate system species $\left(\left[\mathrm{H}_{2} \mathrm{CO}_{3}\right],\left[\mathrm{HCO}_{3}^{-}\right],\left[\mathrm{CO}_{3}^{2-}\right]\right)$, Dissolved Inorganic Carbon $\left(\mathrm{DIC}=\left[\mathrm{H}_{2} \mathrm{CO}_{3}\right]+\left[\mathrm{HCO}_{3}^{-}\right]+\left[\mathrm{CO}_{3}^{2-}\right]\right)$, and the equivalent $\mathrm{pCO}_{2}$ in April and June 97. Some of these species show seasonal trends in conjunction with the seasonal behaviour of the lake.

In an aquatic ecosystem which contains natural weak acids and bases, alkalinity is defined by equation (2) (Morel, 1983):

$$
\begin{aligned}
\mathrm{Alk}= & {\left[\mathrm{HCO}_{3}^{-}\right]+2\left[\mathrm{CO}_{3}^{2-}\right]+\left[\mathrm{NH}_{3}\right]+\left[\mathrm{HS}^{-}\right] } \\
& +2\left[\mathrm{~S}^{2-}\right]+\left[\mathrm{H}_{3} \mathrm{SiO}_{4}^{-}\right]+\left[\mathrm{HPO}_{4}^{2-}\right] \\
& +2\left[\mathrm{PO}_{4}^{3-}\right]+\left[\mathrm{OH}^{-}\right]-\left[\mathrm{H}^{+}\right]-\left[\mathrm{H}_{3} \mathrm{PO}_{4}\right]
\end{aligned}
$$

From Tables 1 and 2, it can be concluded that in the epilimnion of Lake Bourget:

- Dissolved oxygen concentrations prohibit the formation of $\mathrm{HS}^{-}$and $\mathrm{S}^{2-}$.

- $\left[\mathrm{NH}_{3}\right],\left[\mathrm{HPO}_{4}^{2-}\right],\left[\mathrm{PO}_{4}^{3-}\right],\left[\mathrm{H}_{3} \mathrm{PO}_{4}\right],\left[\mathrm{H}_{3} \mathrm{SiO}_{4}^{-}\right],\left[\mathrm{H}^{+}\right]$ and $\left[\mathrm{OH}^{-}\right]$are negligible compared to $\left[\mathrm{HCO}_{3}^{-}\right]$ and $\left[\mathrm{CO}_{3}^{2-}\right]$.

- $\mathrm{HCO}_{3}^{-}$is the major carbonate system species.

Consequently the expression for alkalinity [i.e. equation (2)] can be reduced to equation (3), which is common for most carbonate aquatic systems (Stumm and Morgan, 1981):

$$
\mathrm{Alk}=\left[\mathrm{HCO}_{3}^{-}\right]+2\left[\mathrm{CO}_{3}^{2-}\right]
$$

Since $\left[\mathrm{HCO}_{3}^{-}\right]$is significantly higher $\left[\mathrm{CO}_{3}^{2-}\right]$, then equation (3) can be further simplified to:

$$
\mathrm{Alk}=\left[\mathrm{HCO}_{3}^{-}\right]
$$

The validity of the simplifications has been confirmed by calculating the differences in alkalinity between equations (3) and (4), which remain below $1.6 \%$ for the entire sampling period in Lake Bourget.

Depending on the water composition, calcite precipitation can be expressed in various forms. As previously seen, in Lake Bourget $\left[\mathrm{HCO}_{3}^{-}\right]$is much higher than $\left[\mathrm{CO}_{3}^{2-}\right]$. Consequently the most appropriate form of the calcite precipitation in terms of major compounds is:

$$
\begin{aligned}
& \mathrm{Ca}^{2+}+2 \mathrm{HCO}_{3}^{-} \stackrel{k}{\rightleftharpoons} \mathrm{CaCO}_{3(s)}+\mathrm{CO}_{2}+\mathrm{H}_{2} \mathrm{O} ; \\
& k=10^{5.96} \text { at } 298 \mathrm{~K}
\end{aligned}
$$

In reaction (5), the value of $k$ is calculated with equation (6), which is related to the combination of the $\mathrm{CO}_{2}$ dissolution reaction constant $\left(K_{H}\right)$, the first and second dissociation reaction of carbonic acid constants $\left(K_{a 1}\right.$ and $\left.K_{a 2}\right)$, and the solubility product of calcite $\left(K_{s}\right)$ :

$$
k=\frac{K_{a 2}}{K_{H} * K_{a 1} * K_{s}}
$$

where (Stumm and Morgan, 1981):

$$
\begin{gathered}
K_{a 1}=10^{-6.35} \text { at } 298 \mathrm{~K} \\
K_{a 2}=10^{-10.33} \text { at } 298 \mathrm{~K} \\
K_{H}=10^{-1.43} \text { at } 298 \mathrm{~K}
\end{gathered}
$$

In order to minimize the errors on these thermodynamic constants and the number of chemical parameters, calculation of the saturation index is usually achieved with equation (8) derived from the precipitation reaction [equation (7)]:

Table 2. Calculated parameters of carbonate system species in the epilimnion of the lake during April and June 1997

\begin{tabular}{lcccrr}
\hline Concentration & $\Sigma \mathrm{CO}_{2}(\mu \mathrm{M})$ & $\mathrm{pCO}_{2}(\mu \mathrm{atm})$ & $\mathrm{H}_{2} \mathrm{CO}_{3}(\mu \mathrm{M})$ & $\mathrm{HCO}_{3}^{-}(\mu \mathrm{M})$ & $\mathrm{CO}_{3}^{2-}(\mu \mathrm{M})$ \\
\hline April $2 \mathrm{~m}$ & 2910 & 580 & 34 & 2800 & 13 \\
April $15 \mathrm{~m}$ & 2880 & 570 & 34 & 2780 & 2.5 \\
June $2 \mathrm{~m}$ & 2310 & 350 & 15 & 2220 & 2.5 \\
June $15 \mathrm{~m}$ & 2900 & 1190 & 66 & 2780 & 7 \\
\hline
\end{tabular}




$$
\begin{gathered}
\mathrm{Ca}^{2+}+\mathrm{CO}_{3}^{2-} \stackrel{K_{s}^{-1}}{\rightleftharpoons} \mathrm{CaCO}_{3(s)} ; \\
K_{s}=10^{-8.51} \text { at } 298 \mathrm{~K} \\
\Omega=\frac{\gamma_{2}\left[\mathrm{CO}_{3}^{2-}\right] \gamma_{2}\left[\mathrm{Ca}^{2+}\right]}{K_{s}}
\end{gathered}
$$

where $\gamma_{2}$ is the activity coefficient for bicharged ion calculated according to the Davies relation (Stumm and Morgan, 1981).

Thermodynamical considerations show that precipitation should occur when $\Omega$ is greater than one. However, in the laboratory experiment, homogeneous precipitation occurs for $\Omega>100$ (Stumm and Morgan, 1981), while in environmental conditions heterogeneous precipitation is observed when the saturation index falls in the range [2-11] (Kelts and Hsu, 1978; Stabel, 1986; Hartley et al., 1996; Salmaso and Decet, 1998; Hodell et al., 1998). Values of $\Omega$ for April and June 1997 in Lake Bourget are reported in Table 2.

Photosynthesis and respiration can be classically described according to the following equation (9) (Redfield et al., 1963):

$$
\begin{gathered}
x \mathrm{CO}_{2}+y \mathrm{NO}_{3}^{-}+w \mathrm{H}_{3} \mathrm{PO}_{4}+y \mathrm{H}^{+}+(x+y) \mathrm{H}_{2} \mathrm{O} \\
\stackrel{P}{\rightleftharpoons}(x+2 y) \mathrm{O}_{2}+\left(\mathrm{CH}_{2} \mathrm{O}\right)_{x}\left(\mathrm{NH}_{3}\right)_{y}\left(\mathrm{H}_{3} \mathrm{PO}_{4}\right)_{w}
\end{gathered}
$$

The two main processes depicted by reactions (5) and (9) alter differently the water composition in Lake Bourget:

- Photosynthesis and respiration do not change alkalinity, which is conservative relatively to $\mathrm{CO}_{2}$ variations, whereas DIC can be either taken up by photosynthesis or produced by respiration. The main observable consequence is an increase of $\mathrm{pH}$ when photosynthesis prevails while the opposite is observed when respiration dominates.

- Calcite precipitation decreases both calcium concentration, alkalinity and DIC. According to the stoichiometry of reaction (5) the decrease in alkalinity must be twice the decrease in calcium concentration and DIC. One observable consequence is a decrease in $\mathrm{pH}$.

Therefore, photosynthesis and calcite precipitation have opposite effects on $\mathrm{pH}$ variations.

In order to verify that changes in the ionic composition are exclusively caused by calcite precipitation or photosynthesis-respiration, the concept of residual alkalinity (Alk') can be introduced (AlDroubi et al., 1980; Michard, 1989).

$\mathrm{Alk}^{\prime}$ is defined in order to be constant if the main biogeochemical processes are calcite precipitation [equation (5)] and photosynthesis-respiration [equation (9)]. Therefore, the residual alkalinity can be expressed as follows [equation (10)]:

$$
\mathrm{Alk}^{\prime}=\left[\mathrm{Na}^{+}\right]+\left[\mathrm{K}^{+}\right]+2\left[\mathrm{Mg}^{2+}\right]-\left[\mathrm{Cl}^{-}\right]-2\left[\mathrm{SO}_{4}^{2-}\right]
$$

An alternative definition of alkalinity can be derived from the electroneutrality equation (Sigg et al., 1994) where $\left[\mathrm{H}^{+}\right]$and $\left[\mathrm{OH}^{-}\right]$are neglected:

$$
\begin{aligned}
& {\left[\mathrm{Na}^{+}\right]+\left[\mathrm{K}^{+}\right]+2\left[\mathrm{Ca}^{2+}\right]+2\left[\mathrm{Mg}^{2+}\right]} \\
& =\left[\mathrm{HCO}_{3}^{-}\right]+2\left[\mathrm{CO}_{3}^{2-}\right]+\left[\mathrm{Cl}^{-}\right]+2\left[\mathrm{SO}_{4}^{2-}\right] \\
& \quad+\left[\mathrm{NO}_{3}^{-}\right]
\end{aligned}
$$

Based on equations (3) and (11), the expression of alkalinity can be written in the following way:

$$
\begin{aligned}
\mathrm{Alk}= & {\left[\mathrm{Na}^{+}\right]+\left[\mathrm{K}^{+}\right]+2\left[\mathrm{Ca}^{2+}\right]+2\left[\mathrm{Mg}^{2+}\right] } \\
& -\left[\mathrm{Cl}^{-}\right]-2\left[\mathrm{SO}_{4}^{2-}\right]-\left[\mathrm{NO}_{3}^{-}\right]
\end{aligned}
$$

Combining equations (12) and (10) gives equation (13)

$$
\mathrm{Alk}^{\prime}=\mathrm{Alk}-2\left[\mathrm{Ca}^{2+}\right]-\left[\mathrm{NO}_{3}^{-}\right]
$$

\section{Evidence of calcite precipitation in Lake Bourget}

Figure 2 presents typical temperature profiles in the upper part of the lake from April to August of 1997, when thermal stratification commences. From May, the water column is stratified, and strong thermal gradients do not allow significant water mixing across the thermocline. During this period the thermocline lies between 5 and $10 \mathrm{~m}$ deep, and maximum temperature gradient increases from 2.1 to $4.0{ }^{\circ} \mathrm{C} \mathrm{m}^{-1}$. This thermal structure is similar during the spring and summer of 1998.

Measurements of total dissolved calcium and alkalinity in the epilimnion and metalimnion are reported for the spring and summer of 1997 in Figs 3 and 4.

Calcium concentration and alkalinity profiles

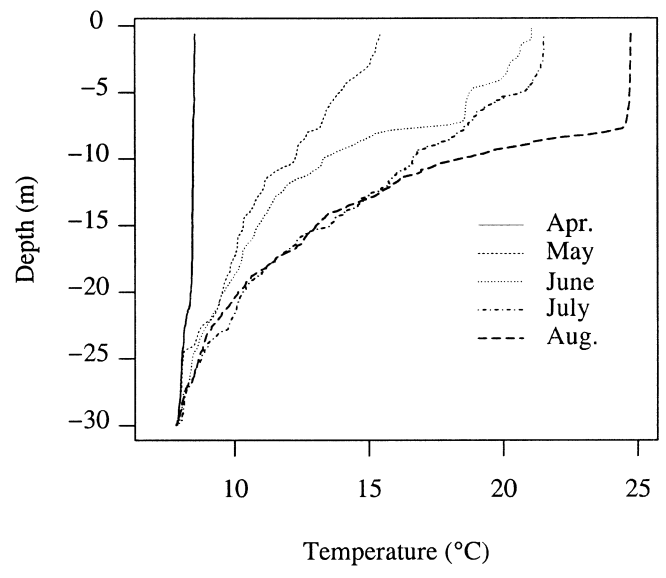

Fig. 2. Temperature profiles during the spring and summer periods of 1997 between surface and $30 \mathrm{~m}$ depth. 


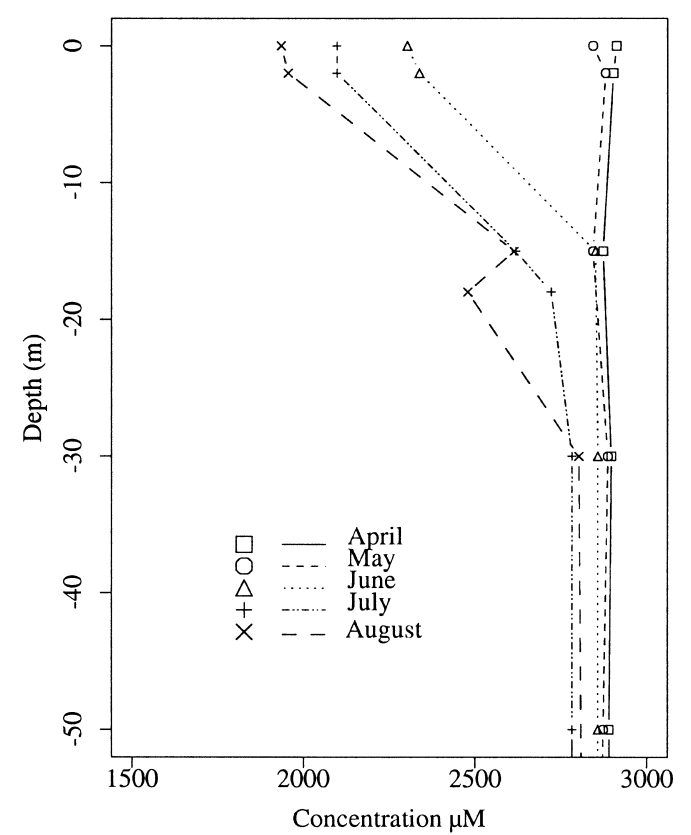

Fig. 3. Alkalinity profiles in the spring and summer periods of 1997 between surface and $50 \mathrm{~m}$ depth.

show a decrease in the epilimnion between May and June. This trend continues until August and after this, calcium and alkalinity depletion stops. These spring and summer data of calcium and alkalinity indicate a linear relationship according to equation (14):

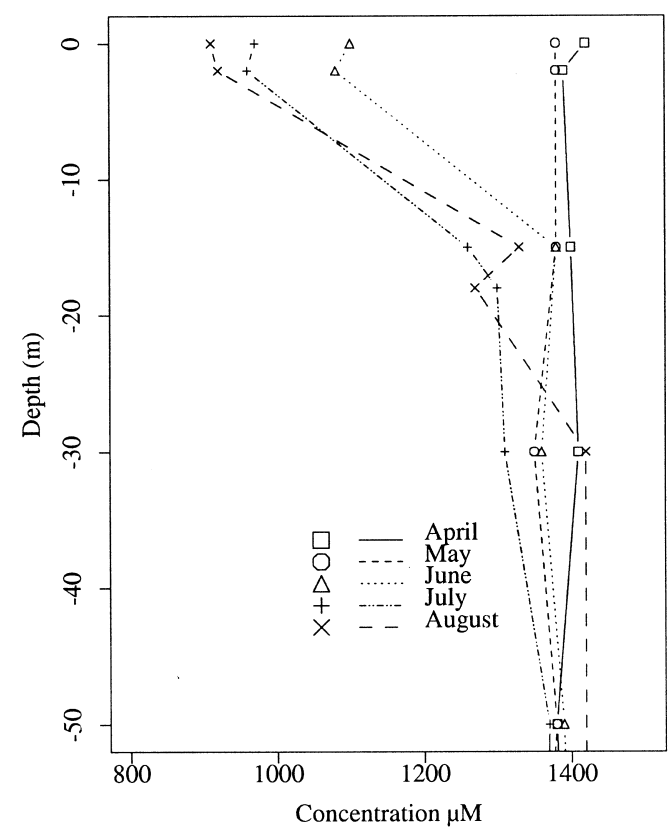

Fig. 4. Calcium profiles in the spring and summer periods of 1997 between surface and $50 \mathrm{~m}$ depth.

$$
\begin{aligned}
\text { Alk } & =(1.9 \pm 0.2)\left[\mathrm{Ca}_{t}\right] \quad \text { with } \rho^{2}=0.965 \text { and } \\
n & =26
\end{aligned}
$$

A similar trend is observed for the spring and summer of 1998 data for calcium and alkalinity, with the following linear relationship [equation (15)]:

$$
\begin{aligned}
\mathrm{Alk} & =(1.8 \pm 0.2)\left[\mathrm{Ca}_{t}\right] \quad \text { with } \rho^{2}=0.933 \text { and } \\
n & =52
\end{aligned}
$$

where $\left[\mathrm{Ca}_{t}\right]$ is the measured total dissolved calcium. Results of ionic dissolved speciation calculations indicates that calcium is partly complexed and that $\left[\mathrm{Ca}_{t}\right]$ differs from $\left[\mathrm{Ca}^{2+}\right]$ by $3.3 \pm 0.6 \%$. Therefore, $\left[\mathrm{Ca}_{t}\right]$ is approximated by $\left[\mathrm{Ca}^{2+}\right]$. According to equation (5), these calcium and alkalinity decreases in the water column are likely to be related to calcite precipitation.

During the spring and summer periods of 1997 and 1998 the residual alkalinity (Alk') remains constant $\left(\mathrm{Alk}^{\prime}=224 \mu \mathrm{M}\right.$, standard deviation $= \pm 15 \mu \mathrm{M}$, $n=75)$. This standard-deviation value remains within the analytical error range. As an example Fig. 5 shows the residual alkalinity profiles during spring and summer periods of 1997. This underlines that the only geochemical process decreasing calcium and alkalinity within the epilimnion is calcite precipitation.

Calculation of calcite saturation index $[\Omega$, equation (8)] reveals that the epilimnic water is supersaturated with respect to calcite from April (Table 2). $\Omega$ reaches the highest value in June at a

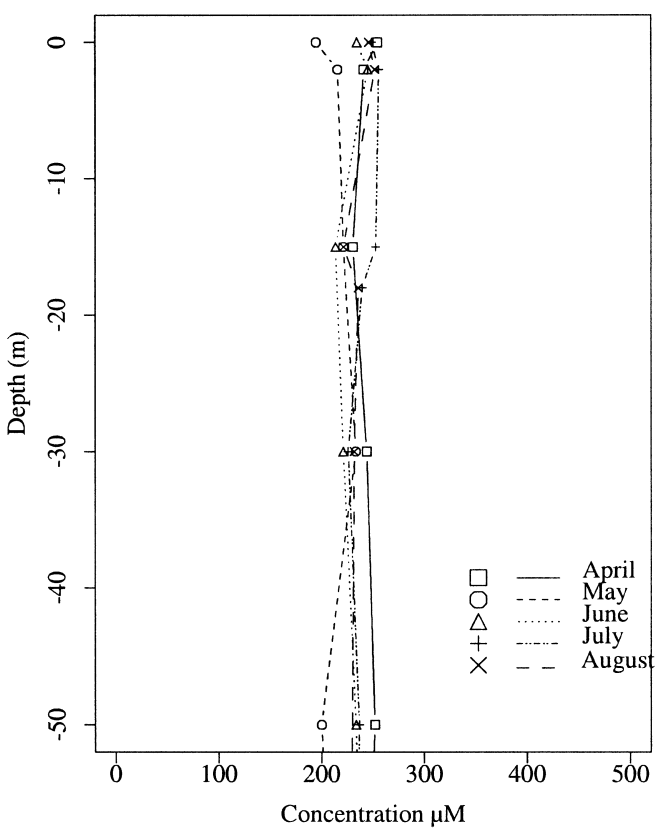

Fig. 5. Residual alkalinity profiles in the spring and summer periods of 1997 between surface and $50 \mathrm{~m}$ depth. 
$2 \mathrm{~m}$ depth with a simultaneous decrease in calcium and alkalinity concentrations.

Since epilimnic water is supersaturated with respect to calcite from April to August of 1997, Alk' remains constant during this period, so we can infer that the calcium concentration decrease observed from June to August is the consequence of calcite authigenic formation. Consequently, calcium and alkalinity profiles (Figs 3 and 4) are a direct and specific tracer of the spatial and temporal widespread of this geochemical process.

However, the spatial resolution of water sampling does not allow the depth-boundary of calcite precipitation to be defined. Indeed, calcium profiles show that this limit should lie between a depth of 2 and $15 \mathrm{~m}$. In order to improve the assessment of spatio-temporal conditions of calcite precipitation, another method must be used.

\section{USING SPECIFIC CONDUCTANCE AS CALCITE PRECIPITATION TRACER}

Contribution of calcium and alkalinity to the specific conductance of Lake Bourget water

Specific conductance or conductivity $\left(C_{25}\right)$ is usually used in lakes for tracing water body mixing or density currents (Carmack et al., 1986; Wüest et al., 1988). In this study specific conductance was applied, focused on the link with lacustrine calcite precipitation. In a recent study on Lake Garda (Salmaso and Decet, 1998) the link between in situ conductivity measurements and calcite precipitation has been emphasized. However, the sampling method did not allow the authors to use conductivity as a precipitation tracer with a good accuracy.

In this paper, it is proposed to use a software sensor of calcite precipitation based on both specific conductance measurements and a relation between conductance and calcium concentration.

Specific conductance is a function of the concentration of the dissolved ions in water. Significant variations of dissolved ion concentrations lead to correlated variations of specific conductance. In order to interpret the specific conductance variations observed in Lake Bourget (Table 1), specific conductance has been calculated following a classical theoretical formula (Charlot, 1974):

$$
C_{25}=\Sigma l_{A} C_{A} z_{A}
$$

where $l_{A}$ is the equivalent conductance of ion $A$ (S $\left.\mathrm{cm}^{2} \mathrm{eq}^{-1}\right), C_{A}$ is the concentration of ion $A$ (mol $\mathrm{cm}^{-3}$ ) and $z_{A}$ is the absolute value of $A$ ion charge.

Values of equivalent conductance at infinite dilution for the dissolved ions (Charlot, 1974) are corrected from the average ionic strength of Lake Bourget $(5 \mathrm{mM})$ by multiplying the values by a 0.96 factor for monocharged ions or a 0.91 factor for bicharged ions (CRC, 1981). They are reported in Table 3.
To perform the calculation of the theoretical specific conductance with equation (16), measured chemical data were used (Table 1) except for $\mathrm{HCO}_{3}^{-}, \mathrm{CO}_{3}^{2-}$ and $\mathrm{Ca}^{2+}$ concentration where the calculated set of chemical parameters were used (Table 2). Figure 6 shows for the periods of April and June of 1997 a reasonable agreement between measured and calculated specific conductance. Between April of 1997 and August of 1997 in the epilimnion (depth $<30 \mathrm{~m}$ ), the calculated specific conductance $\left(C_{25}^{c}\right)$ showed a linear relationship with the measured specific conductance $\left(C_{25}^{m}\right)$ presented in equation (17):

$$
\begin{gathered}
C_{25}^{c}=1.03 * C_{25}^{m}-10 \quad \text { with } \rho^{2}=0.965 \\
n=22 ; \quad C_{25}^{c} \quad \text { and } \quad C_{25}^{m} \quad \text { in } \mu \mathrm{S} \mathrm{cm}^{-1}
\end{gathered}
$$

Between April and August 1997, theoretical calculations of specific conductance show that the ion concentrations included in residual alkalinity $\left(\mathrm{Alk}^{\prime}\right)$ contributed approximately $21 \%$ of the specific conductance. Moreover, the individual variation of each ion concentration present in $\mathrm{Alk}^{\prime}$ over the period under study never exceeds $10 \%$.

Therefore, the observed specific conductance variations are likely to be related only to changes in calcium and $\mathrm{HCO}_{3}^{-}$concentrations. Based on this finding, equation (16) can be expressed as [equation (18)]:

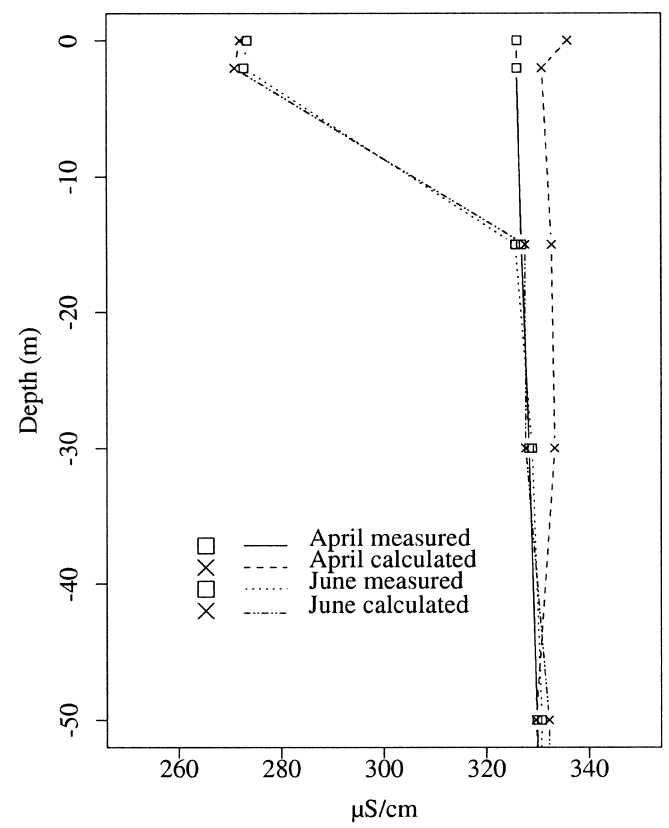

Fig. 6. Comparison of measured and calculated specific conductance $\left(C_{25}\right)$ in April and June 1997 between surface and $50 \mathrm{~m}$ depth. 
Table 3. Equivalent conductance of separate ions at $25^{\circ} \mathrm{C}$ and $I=5 \mathrm{mM}$

\begin{tabular}{|c|c|c|c|c|c|c|c|c|c|}
\hline Ion & $\mathrm{Ca}^{2+}$ & $\mathrm{Mg}^{2+}$ & $\mathrm{Na}^{+}$ & $\mathrm{K}^{+}$ & $\mathrm{HCO}_{3}^{-}$ & $\mathrm{CO}_{3}^{2-}$ & $\mathrm{Cl}^{-}$ & $\mathrm{NO}_{3}^{-}$ & $\mathrm{SO}_{4}^{2-}$ \\
\hline Equ. cond. $\mathrm{S} \mathrm{cm} \mathrm{eq}^{-1}$ & 54.1 & 48.3 & 48.1 & 70.6 & 42.7 & 63.1 & 73.2 & 68.5 & 72.0 \\
\hline
\end{tabular}

$$
C_{25}=l_{\mathrm{Ca}^{2+} \mathrm{Ca}^{2+}}\left[\mathrm{Ca}^{2+}\right]+l_{\mathrm{HCO}_{3}^{-}} z_{\mathrm{HCO}_{3}^{-}}\left[\mathrm{HCO}_{3}^{-}\right]+\epsilon
$$

where $\epsilon$ represents the contribution to the specific conductance of all the major ions present in $\mathrm{Alk}^{\prime}$, and of the nitrate and carbonate species. From the chemical data of 1997 in the epilimnion $(n=22)$ and by using Table 3 , it is verified that $\epsilon$ is a constant equal to $64.9 \pm 1.9 \mu \mathrm{S} \mathrm{cm}^{-1}$.

By assuming that $\left[\mathrm{Ca}_{t}\right]=\left[\mathrm{Ca}^{2+}\right]$, combining equations (3), (14) and (18) and by using Table 3, the following theoretical relation between conductivity and calcium concentrations is derived:

$$
\begin{aligned}
& {\left[\mathrm{Ca}_{t}\right]=5.32 * C_{25}-369} \\
& \text { with }\left[\mathrm{Ca}_{t}\right] \text { in } \mu \mathrm{M} \text { and } C_{25} \text { in } \mu \mathrm{S} \mathrm{cm}^{-1}
\end{aligned}
$$

Figure 7 shows the spring and summer total dissolved calcium and specific conductance data in the epilimnion for 1997 and 1998, their best linear fit [equation (20)] and the derived theoretical relationship [equation (19)]. The theoretical model and the linear fit are in close agreement:

$$
\begin{aligned}
& {\left[\mathrm{Ca}_{t}\right]=5.37 * C_{25}^{m}-386 \quad \rho^{2}=0.959} \\
& \text { and } n=75 ; \quad \text { with }\left[\mathrm{Ca}_{t}\right] \quad \text { in } \mu \mathrm{M} \text { and } \\
& C_{25}^{m} \quad \text { in } \mu \mathrm{S} \mathrm{cm} \mathrm{cm}^{-1}
\end{aligned}
$$

Equation (20) allows the calculation of the calcium concentration from specific conductance measures

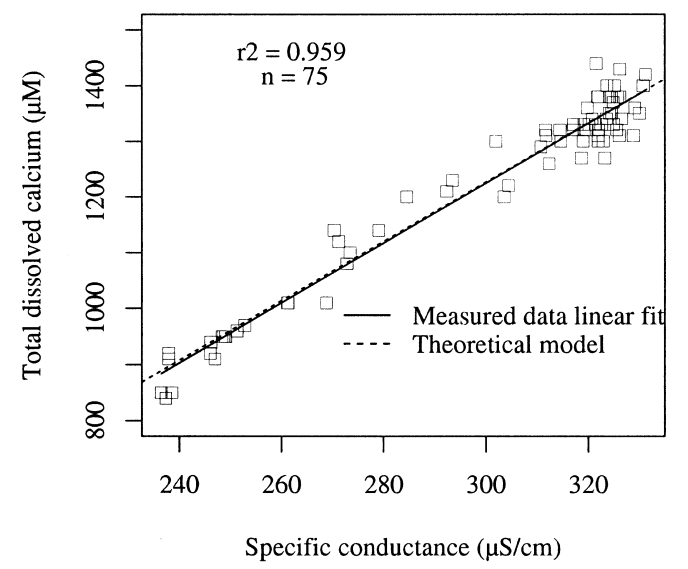

Fig. 7. Correlation between specific conductance $\left(C_{25}\right)$ and total dissolved calcium in the epilimnion for 1997 [April to August] and 1998 [January to August]. The related error on $C_{25}$ is $\pm 2 \%$ and for $\left[\mathrm{Ca}_{t}\right]$ is $\pm 5 \%$. with an accuracy of $\pm 10 \%$ and with a spatial depth resolution of $0.15 \mathrm{~m}$.

Since the calcium concentration is directly related to authigenic calcite precipitation in Lake Bourget (see the section for evidence of calcite precipitation in Lake Bourget), specific conductance provides an in situ self-consistent tracer of calcite precipitation.

Assessment of the spatio-temporal pattern of calcite precipitation using specific conductance

From equation (20) and the specific conductance profiles, the calcium profiles for the global sampling period were computed (April 1997-December 1998). Profiles obtained with a high spatial resolution $(0.15 \mathrm{~m})$ are plotted in a time-depth evolution diagram (Fig. 8) using Surfer32 Golden Software ${ }^{(}$. In a similar manner, the temperature evolution profile is presented in Fig. 9 in order to show the thermal structure of the upper part of the water column during the whole period. According to equation (5), the calcium concentrations are directly related to the production of authigenic calcite. Therefore, this diagram exposes a spatio-temporal pattern of calcite precipitation and corroborates the following conclusions:

- A fair similarity is observed between the two years concerning the spatial pattern of the precipitation process.

- The depth limit of the precipitation zone is located for the two years between 7 and $10 \mathrm{~m}$ depth, corresponding exactly to the mixed layer. Calcite precipitation is also strongly linked to the thermal structure of the epilimnion.

- Depending on a different meteorological forcing context, in 1998, calcite precipitation is starting one month earlier than in 1997.

- Minimum calcium concentration is achieved in August and is equal to $900 \pm 20 \mu \mathrm{M}$ in the precipitation zone for both 1997 and 1998.

In order to quantify and compare the amount of calcite precipitated at point B in 1997 and 1998, an integration of computed calcium profiles was performed. The integration was conducted over the upper $30 \mathrm{~m}$ under the surface. The physical structure of the epilimnion and of the metalimnion infer that no significant vertical mixing occurs during the two precipitation periods between this $0-30 \mathrm{~m}$ column and the underlying water (June-August 1997 and May-August 1998). This system can also be considered as closed from an external supply of calcium during the precipitation periods. Complete winter water body mixing begins in September and ends in January (Bournet, 1996). Therefore, it does 


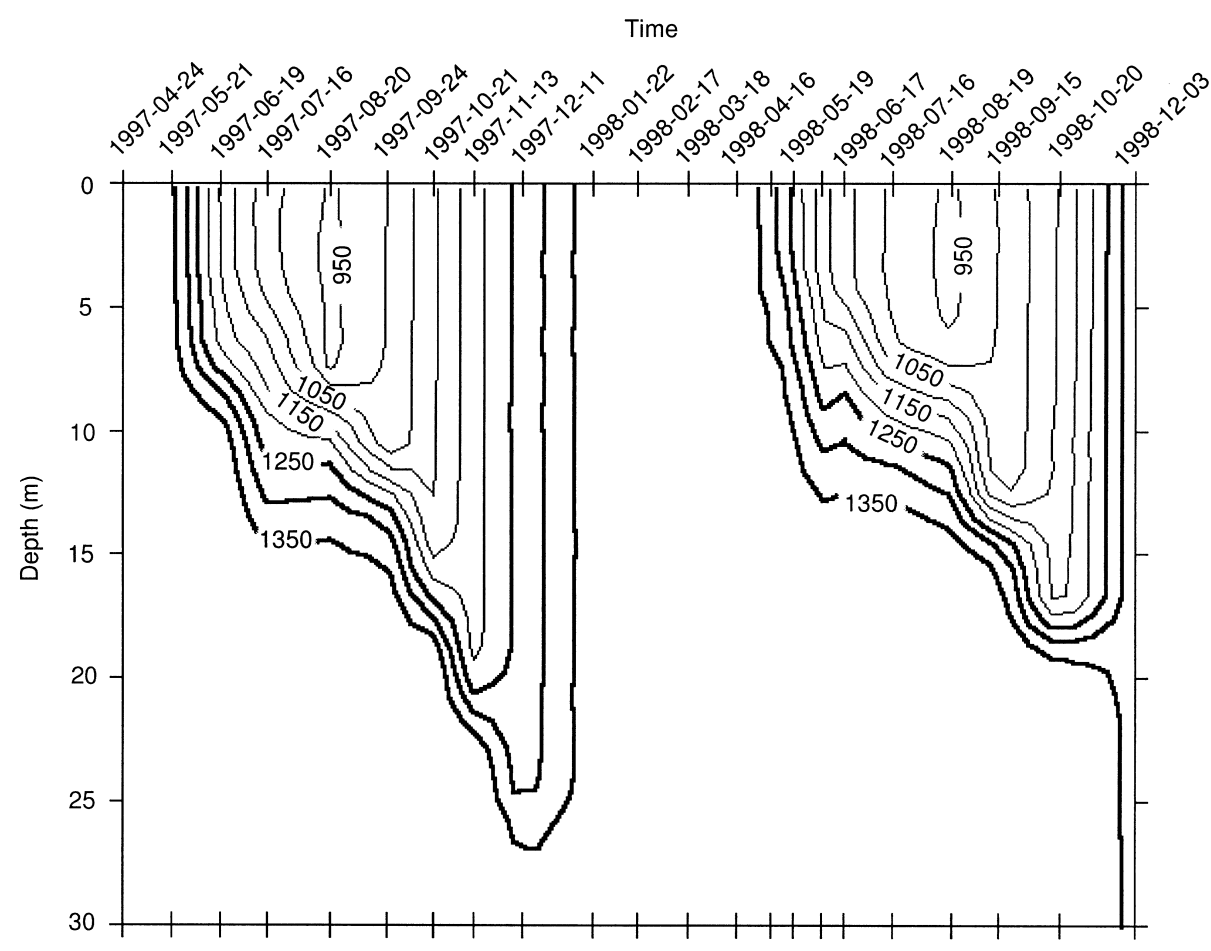

Fig. 8. Time-depth evolution diagram of calcium concentration (in $\mu \mathrm{M}$ ) in the $0-30 \mathrm{~m}$ depth layer for 1997 and 1998. Dates on the $x$-axis represent the dates of field survey.

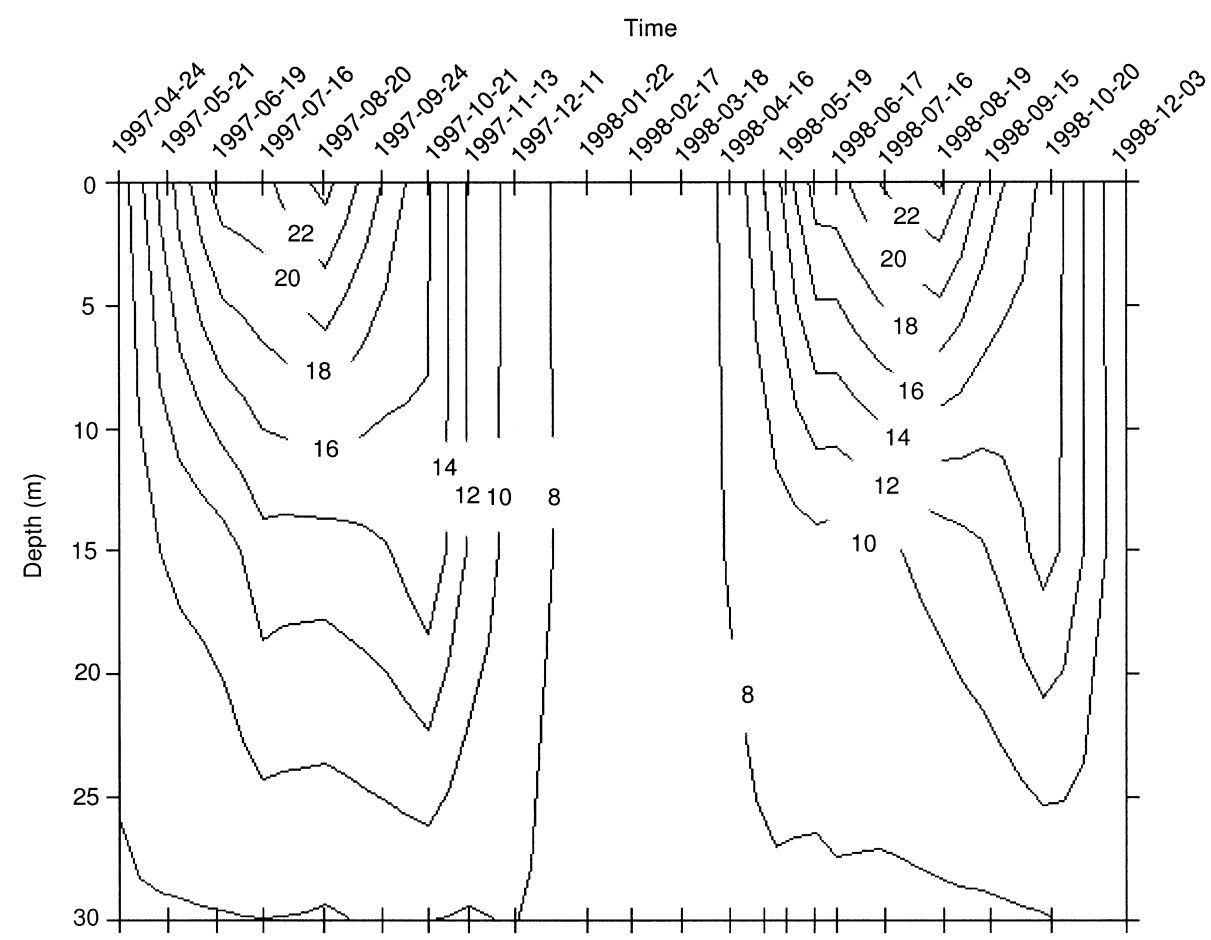

Fig. 9. Time-depth evolution diagram of temperature (in Celsius degrees) in the $0-30 \mathrm{~m}$ depth layer for 1997 and 1998. Dates on the $x$-axis represent the dates of field survey. 
not influence the evaluation of precipitated calcite during spring and summer. Evolution of the calcium stock and of the amount of produced calcite in the upper $30 \mathrm{~m}$ is reported in Table 4 for the 1997 and 1998 precipitation periods. Calcium stock refers to the amount of dissolved calcium (mol) contained in the same layer at a given time. The amount of calcite produced is calculated by the difference between the $\mathrm{Ca}$ stock at an initial time before the beginning of calcite precipitation (April 97 or April 98) and the Ca stock at a given time. As there is no $\left[\mathrm{Ca}_{t}\right]$ variations below $30 \mathrm{~m}$ in the lake, the amount of calcite produced in the upper $30 \mathrm{~m}$ is also the amount of calcite produced in the whole lake. All the results are expressed in mol in the upper $30 \mathrm{~m}$ per $\mathrm{m}^{-2}$ of lake surface.

These results show that the amount of authigenic calcite produced is the same in 1997 and 1998 given a range of experimental and calculation uncertainties $( \pm 10 \%)$. A linear extrapolation from a watercolumn to the lake volume concerned by the precipitation process, yields an estimate of the calcite production of $16,000 \pm 1600$ ton $\mathrm{yr}^{-1}$ as $\mathrm{CaCO}_{3}$. Although this extrapolation is based on a horizontal homogeneity which is strictly not assessed, the order of magnitude of the yearly calcite production is valid. This authigenic mineral formation can be compared to the yearly phytoplanktonic production which is approximately 18,000 tons/year according to the Redfield stoichiometry $\left(3550 \mathrm{~g} \mathrm{~mol}^{-1}\right)$ (Vinçon-Leite, 1991).

\section{CONCLUSIONS}

This study shows that in Lake Bourget variations of specific conductance in the epilimnion during the spring and summer periods are related in a univocal way to the spatial and temporal evolution of the dissolved calcium and alkalinity concentrations. This has been verified as follows:

- The observed conductivity profiles can be theoretically calculated with very good accuracy.

- The dissolved calcium concentration is well correlated with specific conductance.

Moreover, it was clearly shown that dissolved calcium and alkalinity variations in the epilimnion of the lake are exclusively related to calcite precipitation. It was demonstrated that in a natural large

Table 4. Calcium stock evolution (mol) based on the integration of the computed Ca profiles in the upper $30 \mathrm{~m}$ of the lake and calcite produced $\left(\mathrm{mol} \mathrm{m}^{-2}\right)$ in the water column of the lake during the spring and summer of 1997-1998

\begin{tabular}{lccc}
\hline Date & April & August & September \\
\hline Ca stock 1997 & 40.1 & 35.3 & 35.3 \\
Calcite produced 1997 & 0 & +4.8 & +4.8 \\
Ca stock 1998 & 39.5 & 35.3 & 34.7 \\
Calcite produced 1998 & 0 & +4.2 & +4.8 \\
\hline
\end{tabular}

lake ecosystem, specific conductance, generally used in laboratory investigations on calcite precipitation (House and Donaldson, 1986; Kleiner, 1988; Hartley et al., 1997), is able to trace by itself, with a good spatial resolution, the calcite precipitation. The main advantages proposed by this method are: (1) Specific conductance can be measured in situ; (2) using a conductivity sensor permits easy and rapid data acquisition with a very high temporal and spatial resolution.

Using this method on Lake Bourget, the first assessment of the spatio-temporal pattern of calcite precipitation reveals that the process occurred in 1997 and 1998 in the same layer. Restricted to a quite short period (from May-June to August-September), calcite precipitation shows a reproducible intensity over this two-year period. Evaluation of the precipitated amounts leads to a value of 16,000 \pm 1600 ton $\mathrm{yr}^{-1}$ as $\mathrm{CaCO}_{3}$, making this reaction a major particulate producing process in the lake.

Specific conductance is an excellent, reliable and easy-to-measure in situ tracer of calcite precipitation in Lake Bourget. Moreover, similar physical and chemical characteristics of other alpine lakes should allow one to extend this method.

\section{REFERENCES}

Al-Droubi A., Fritz B., Gac J. and Tardy Y. (1980) Generalized residual alkalinity concept; application to prediction of the chemical evolution of natural waters by evaporation. Amer. J. Sci. 280, 560-572.

APHA (1989) Standard Methods for the Examination of Water and Wastewater, 17th ed. APHA, AWWA, WPCF, Washington, DC.

Bournet P. (1996) Contribution à l'étude hydrodynamique et thermique du lac du Bourget. Ph.D. thesis, Ecole Nationale du Génie Rural, des Eaux et des Forêts, France.

Carmack E., Wiegand R., Daley R., Gray B., Jasper S. and Pharo C. (1986) Mechanisms influencing the circulation and distribution of water mass in a medium residence-time lake. Limnol. Oceanogr. 31, 249-265.

Charlot G. (1974) Chimie Analytique Quantitative, 6th ed. Masson, Paris.

CRC (1981) Handbook of Chemistry and Physics, 61st ed. CRC Press, Boca Raton, FL.

Decet F. and Salmaso N. (1997) Indagini preliminari sulle caratteristiche chimiche dei principali affluenti e dell'emissario del Lago di Garda. Acqua Aria 7, 91-97.

Gaillard J. (1995) Limologie chimique: principes et processus. In Limnologie Générale, eds R. Pourriot and M. Meybeck, pp. 115-156. Masson, Paris.

Hartley A., House W., Callow M. and Leadbetter B. (1996) The use of microelectrodes to study the precipitation of calcite upon algal biofilms. J. Colloid. Interface Sci. 183, 498-505.

Hartley A., House W., Callow M. and Leadbetter B. (1997) Coprecipitation of phosphates with calcite in the presence of photosynthesizing green algae. Water Research 31(9), 2261-2268.

Hodell D., Scheske C., Fahnenstiel G. and Trobbins L. (1998) Biologically induced calcite and its isotopic composition in Lake Ontario. Limnol. Oceanogr. 43(2), 187199.

House W. and Donaldson L. (1986) Adsorption and coprecipitation of phosphate on calcite. J. Colloid Interf. Sci. 112, 309-324. 
Kelts K. and Hsu K. (1978) Freshwaters carbonate sedimentation. In Lakes: Chemistry, Geology, Physics, ed. A. Lerman, pp. 295-323. Springer-Verlag.

Kleiner J. (1988) Coprecipitation of phosphate with calcite in lake water: a laboratory experiment modelling phosphorus removal with calcite in Lake Constance. Water Research 22(10), 1259-1265.

Kuchler-Krischun J. and Kleiner J. (1990) Heterogeneously nucleated calcite precipitation in Lake Constance. A short time resolution study. Aquatic Sciences 52(2), 176-197.

Masson M., Canu S., Grandvalet Y. and Lyngaard-Jensen A. (1998) Software sensor design based on empirical data. In: International workshop on applications of neural networks to ecological modelling (Toulouse).

Michard G. (1989) Equilibres Chimiques dans les Eaux Naturelles, 1st ed. Publisud, Paris.

Morel F. (1983) Principles of Aquatic Chemistry, 1st ed. Wiley Interscience, New York.

Murphy T., Hall K. and Yesaki I. (1983) Coprecipitation of phosphate with calcite in a naturally eutrophic lake. Limnol. Oceanogr. 28(1), 58-69.

Otzuki A. and Wetzel R. (1972) Coprecipitation of phosphate with carbonates in a marl lake. Limnol. Oceanogr. 17, 763-767.

Podda F. and Michard G. (1994) Mesure colorimétrique de l'alcalinité. C.R. Acad. Sci. Paris. série II 319, 651657.

Redfield A., Ketchum B. and Richards F. (1963) The influence of organisms on the composition of seawater. In The Sea, ed. M. Hill, pp. 26-77. Wiley Interscience.

Salmaso N. and Decet F. (1998) Interactions of physical, chemical and biological processes affecting the seasonality of mineral composition and nutrient cycling in the water column of a deep subalpine lake (Lake Garda, Northern Italy). Arch. Hydrobiol. 142(4), 385-414.

Sarazin G., Michard G. and Prevot F. (1999) A rapid and accurate spectroscopic method for alkalinity measurements in sea water samples. Water Research 33(1), 290294.

Sigg L., Stumm W. and Behra P. (1994) Chimie des Milieux Aquatiques. Masson ed., Paris.

Stabel H. (1986) Calcite precipitation in Lake Constance: chemical equilibrium, sedimentation, and nucleation by algae. Limnol. Oceanogr. 31, 1081-1093.

Stabel H. and Chondrogianni C. (1988) Seasonal shifts in the grain size of settling particles in Lake Constance. Water Research 22(2), 251-255.

Stumm W. and Morgan J. (1981) Aquatic Chemistry, 2nd ed. Wiley Interscience, New York.

Vinçon-Leite B. (1991) Contribution de la modélisation mathématique à l'étude de la qualité de l'eau dans les lacs sub-Alpins: le lac du Bourget (Savoie). Ph.D. thesis, ENPC.

Vinçon-Leite B., Tassin B. and Jaquet J. (1995) Contribution of mathematical modelling to lake ecosystem understanding: Lake Bourget (Savoie, France). Hydrobiologia 300/301, 433-442.

Vinçon-Leite B., Bournet P., Gayte X., Fontvieille D. and Tassin B. (1998) Impact of a flood event on the biogeochemical behaviour of a mesotrophic alpine lake: Lake Bourget (Savoy). Hydrobiologia 373/374, 361-377.

Weilenmann U. (1986) The role of coagulation for the removal of particles by sedimentation in lakes. Ph.D. thesis, Swiss Federal Institute of Technology. Univ. Zürich.

Wüest A., Imboden D. and Schurter M. (1988) Origin and size of hypolimnetic mixing in Urnersee, the southern basin of Vierwaldstättersee (Lake Lucerne). Schweiz. Z. Hydrol. 50, 40-70. 